\title{
IN SIGNIS RISUM
}

Amós Coêlho da Silva*

(Universidade do Estado do Rio de Janeiro)

ReSumo: Plauto fundou na Helenização de Roma um teatro cômico cheio de humor. Apropriou-se o poeta de fragmentos helênicos da comédia grega e os eternizou através de poetas nacionais diversos.

Palavras-Chave: humor; intertextos helênicos; comédia.

\section{IN SIGNIS RISUM}

ABSTRACT: Plautus founded in Hellenization of Rome a comic theater full of humour. The poet of Greek comedy Hellenic fragments appropriated and eternalized them through diverse national poets.

KEYWORDS: humour; Hellenic intertexts; comedy

\section{Introdução}

Os dicionários especializados, como os citados abaixo: Dicionário de Teatro e Dicionário de Termos Literários, não possuem o verbete "humor", por isso retiramos de Antônio Houaiss Eletrônico:

1. Rubrica: história da medicina. Líquido secretado pelo corpo e que era tido como determinante das condições físicas e mentais do indivíduo [Na Antiguidade clássica contavam-se quatro humores: sangue, bile amarela, fleuma ou pituíta e bile negra ou atrabílis].

No entanto, existem muitos projetos de estudos e ensaios sobre "humorismo". Cícero (106 a 43 a.C.), De Oratore, II, LVIII, se preocupou com o assunto:

Atque illud primum, qui sit ipse risus, quo pacto concitetur, ubi sit, quomodo exsistat, atque ita repente erumpat, ut eum cupientes tenere nequeamus, et quomodo simul latera, os, uenas, uultum, oculos occupet, uideret Democritus

E aquele primeiro ponto: o que seria o próprio riso, por qual combinação se provocaria, de onde viria, de que modo se manifestaria, e que tal força irrompe repentinamente, que, mesmo que desejemos contê-lo, não

\footnotetext{
*E-mail: amoscoelho@uol.com.br
} 
conseguimos, e, que tal força ocupa, ao mesmo tempo, o nosso peito, boca, veias, rosto, olhos? Haja vista em Demócrito ${ }^{1}$.

No panteão grego, há a antropomorfização do sarcasmo como deus do riso, que é Momo, uma divindade feminina em Hesiodo, "Teogonia", 214 é filha de Nix, a Noite, e irmã das Hespérides; o termo Momo tem sido ligado ao verbo 'mokãn' ou 'mokâsthai', "ridicularizar, chasquear, zombar, escarnecer" (BRANDÃO,1994/1986: 228). Apud Paulo Rónai (1980), Risum in lacrimis vertit, transforma o riso em lágrimas é uma expressão atribuída por João Ribeiro a um satírico antigo que pretendia demonstrar que o humorismo, muitas vezes, encobre grandes melancolias.

Em Aristóteles (384-322 a.C.), há uma reflexão sobre o riso como apanágio do homem. Até mesmo, o filósofo estagirita abriu um projeto de estudo sobre o melancólico, com sua tendência à introspecção, à meditação e à criatividade artística.

Mas o que há de poético no riso da comédia? Na Poética (Capítulo 4), Aristóteles, atribui a origem da poesia a duas causas; são duas causas naturais desde a infância: a) uma diferença ocorre entre o homem e o animal, dada uma aptidão peculiar ou instintiva no homem em imitar; daí, o homem adquire conhecimento, isto é, pela imitação e b) sentem prazer quando imitam. Em seguida, define a comédia como imitação de homens inferiores, envolvidos em certos tipos de vícios ridículos: (esti tò gueloîon mórion), está numa parte risível. (Poét. 5, 33) Conclui que risível é o feio ou o defeito sem dor e sem dano. Giovanni Lombardo nos fala, sobre esta passagem aristotélica (Poética, 5,1, 1449a.), como sendo a "catarse cômica" (p. 97):

\begin{abstract}
A catarse torna-se então possível precisamente porque a 'mímesis', obrigando as emoções a morderem o freio da arte, "purifica" o seu tumulto na clareza de uma forma. Mas como se realiza esta purificação quando, em vez da acção séria da tragédia, a cena representa a acção ridícula da comédia? Temos indicação, através de vários testemunhos, que a par da catarse trágica, Aristóteles deve ter teorizado (provavelmente no segundo livro da "Poética") também uma catarse cômica. Embora representando assuntos de pouca conta, a comédia - explica Aristóteles - não abarca toda a espécie de 'kakía', de "vícios", de "vileza", mas vira-se apenas para o 'aischron', o "feio", do qual o 'geleion', o "ridículo", é precisamente uma participação indolor.
\end{abstract}

Portanto, podemos identificar o "poético" na linguagem simbólica do cômico. Assim, o admite Ernst Cassirer que afirma que em lugar de definir o homem como um "animal rationale", deveríamos defini-lo como um "animal symbolicum", e assim poderíamos revelar a sua ação lúdica no seio social, ou a experiência da poíesis, da produção do "real" como uma marca subjetiva e, por vezes, artística.

Plauto (250 - 184 a. C.), Titus Maccius (ou Maccus) Plautus, não é apenas um tradutor para uma língua bárbara dos exempla helênicos, ille in signis ridiculum vertit, ele transforma o gracejo em símbolos ${ }^{2}$, como bem anotou Ettore Paratore (1983: 45):

Nos prólogos e nos "argumenta" das comédias plautinas, diz-se, às vezes, que o poeta "vortit barbare" o modelo grego: a frase parece revelar uma aquiescência supina ao original, seja pelo uso do advérbio "barbare", que devia soar estranho nos palcos romanos, ao passo que era natural para ouvidos gregos a respeito duma versão do grego para uma língua estrangeira, seja pelo significado do verbo "vorto", que indica precisamente a acção de traduzir.

\footnotetext{
${ }^{1}$ Diz-se que o filósofo grego Demócrito (s. V a.C.), fundou, com seu mestre Leucipo, a teoria do átomo, mas riu muito contra o pensamento do seu antecessor Heráclito (s. VI - V a.C.).

${ }^{2}$ A tradução dos textos é nossa.
} 
Pensamos também ao contrário, ou seja, na esteira de outros estudiosos e, por isso, concordamos com Ettore Paratore sobre o exagero da observação. Há muita analogia entre os dois mundos. O povo romano conviveu com os gregos desde um passado bastante remoto, e não apenas a partir da chegada do escravo grego Lívio Andronico em 240 a.C. Como observa Meillet (1977), já havia suficiente interação de linguagem entre gregos e romanos para que o favor do público, e no caso de Plauto de origem plebeia, nunca abandonasse a audiência de uma peça sua. E os primeiros textos da comédia plautina, que sobreviveram completos (ou quase), demonstram isso: C'est par la plèbe de Rome que sont entrées les plus anciens mots grecs du latin. (...) De ces premiers textes, les seuls qui aient survécu à l'état d'oeuvres complètes sont des comédies (...). (MEILLET, $1977:$ 108-9) ${ }^{3}$

Pórcio Licínio, apud Ettore Paratore (1983), afirmou:

Punico bello secundo Musa pinnato gradu

Intulit se bellicosum in Romuli gentem feram.

Na segunda guerra púnica, a Musa, com passos alados,

Se transferiu para o valente povo belicoso de Rômulo.

O que está bem de acordo com o pensamento horaciano:

Graecia capta ferum victorem cepit et artes Intulit agresti Latio. (Horácio, Epístolas 2, 1, 156)

A Grécia subjugada superou o seu feroz vencedor

E introduziu as artes no agreste Lácio.

Eis, acima, uma síntese da Pax Romana, a Paz Romana. Por artes, resume Horácio (65 - 8 a.C.) a filosofia, religião, teatro, a gramática, etc. Na religião, os romanos receberam o fluxo de influência helênica no seu panteão; assim, deuses gregos aos romanos fixarão características: Zeus a Júpiter, Hera à deusa Juno, Afrodite à bela Vênus, Atená à sábia Minerva, Apolo se impõe como Apolo mesmo etc., cujo sincretismo passará a ser a missão dos romanos.

Houve, é claro, a dominação etrusca entre os séculos VII - VI a.C. É bem verdade também que os descendentes de Rômulo aceitaram de bom grado ritos religiosos, elementos da engenharia etrusca etc. Mas, paradoxalmente, foi com eles que os romanos aprenderam o alfabeto grego. Na expressão de Maria Helena da Rocha Pereira o que se entende por Cultura Romana não pode ser desligado do próprio processo de Helenização de Roma, assinalado por Horácio pela cruel espada frente ao esteta helênico, embora tenha de se reconhecer que, mais do que imitação, se deve falar de assimilação criadora... (PEREIRA, 1982: 37)

Consideremos as palavras de Arnaldo Momigliano (1975: 24-5):

A maioria dos escritores se sujeitou e foi recompensada. Lívio Andrônico, ex-escravo grego, alcançou respeitabilidade e influência; foi-lhe permitido ter o seu próprio "collegium", um privilégio cobiçado (Festo p. 333 M. = 446 L). Ênio foi levado da Sardenha para Roma por Catão: uma informação (Corn. Nep. "Cato" 1,4).

Mas há também singularidade nas apropriações de Plauto. Aliás, os poetas latinos imitaram na perspectiva de buscar superar o modelo. Como observa Meillet, na verdade, Roma foi a criadora do humanismo (MEILLET, 1977: 10): Rome a imité la

\footnotetext{
${ }^{3}$ É pela plebe romana que entraram as mais antigas palavras gregas do latim. [...] Destes primeiros textos, os únicos que sobreviveram em estado de obras completas são as comédias.
} 
Grèce, mais à sa manière et en faisant oeuvre propre: l'humanisme est dî̀ à Rome. Tanto é assim que se desvanece a lembrança de uma autoria originalmente grega pelo benefício do stilus do cômico de Plauto, que é um poeta úmbrio, o mais admirado por Molière (1622 - 1673)... "Stilus" com "i", quer dizer, propriamente em língua latina. Enquanto "stylus" é uma grafia consagrada pelos franceses: grahie du fr. "style" est due à un faux rapprochement avec $\sigma \tau v \lambda o \varsigma^{4}$ (stylos - transcrição nossa), (ERNOUT et MELLET, 1985: stilus)

Pode-se afirmar que a prática da imitatio, que estava sob o zelo da estética da época, haja vista a manifestação de Terêncio, Publius Terentius Afer (185 - 159 a.C), in prólogo de Os Adelfos, onde defende a originalidade da sua autoria e a do Plauto, na questão da contaminatio, técnica de adaptação de passagens literárias gregas em encenação no palco latino:

Synapothnescontes Diphili comoediast:

Eam Commorientes Plautus fecit fabulam. (v. 6 - 7)

Há a comédia Synapothnescontes de Dífilo

E nela Plauto se inspirou para fazer Commorientes ${ }^{5}$;

Pois bem, diz-nos o Poeta acima que Plauto deixou em branco a parte da qual ele, Terêncio, se apropriou:

Furtumne factum existumetis an locum Reprehensum, qui praeteritus neclegentiast. (v. 13-14)

E julgai se houve acaso algum furto ou se o trecho

Retomado, não foi negligenciado e posto de lado.

Terêncio recorreu, pois, à mesma contaminação plautina, e não à ênfase de encenações episódicas com o mesmo tom de bufonaria, ou les scènes gaies, as cenas de gaiatices, porém, faire rire les honnêtes gens, fazer rir as pessoas honestas. (HUMBERT, 1932: 58)

Por extensão, se podemos afirmar esses comentários sobre as inovações artísticas destes cômicos, o mesmo se poderá defender sobre o terceiro dos principais teatrólogos de Roma: Sêneca (CARDOSO, 2011: 16). Os historiadores já observaram como a aculturação é inevitável e é, em contraste com a identidade nacional, uma busca pelo universal, o que podemos constatar pelo poeta Terêncio: Homo sum: humani nihil a me alienum puto, (Heautontimoroúmenos, ou I, 1, 25), Sou humano: julgo que nada do Homem considero alheio a mim, ou (apud CARDOSO, 2011: 16):

Paul Veyne (1979) analisa a helenização de Roma [...] que busca "entrar na cultura internacional" e "sofre a atração dos valores helênicos". Para o autor, o helenização - já iniciada anteriormente, mas consolidada no século III a.C. [...] mostra que Roma quis helenizar-se para se afirmar e que a apropriação dos modelos equivaleu à de qualquer outro espólio obtido pelo conquistador. Roma se helenizou, entretanto, sem perder a identidade. E criou uma literatura e, por extensão, um teatro, em que os sinais da romanidade são evidentes.

É interessante observar que, em meio a dificuldades na identificação da autoria de peças cômicas, o estilo foi um guia seguro na investigação filológica de Marco Terêncio Varrão (116 - 27 a.C.), apud (AULO GÉLIO, vol. I, 3,3, 4): Plautissimi

\footnotetext{
${ }^{4}$ Roma imitou a Grécia, mas à sua maneira, fazendo nisso obra própria: o humanismo se deve a Roma.

5 Tem o mesmo significado grego e significa "aqueles que devem morrer juntos".
} 
uersus, versos inteiramente de Plauto. É assim que, na classificação das comédias, temos, das cento e trinta peças anteriormente atribuídas a Plauto, a que só admite as vinte e uma que se consagraram historicamente pela nomenclatura "varronianas", com o timbre de autêntica autoria, com a seguinte ordem alfabética: Amphitruo, Asinaria, Aulularia, Bacchides, Captivi, Curculio, Casina, Cistellaria, Epidicus, Mostellaria, Menaechmi, Miles Gloriosus, Mercator, Persa, Poenulus, Pseudolus, Rudens, Stichus, Trinummus, Truculentus e fragmentos de Vidularia,) Noventa delas são espúrias. Há 19 peças de autenticidade duvidosa, chamadas pseudo varronianas, dentre as quais Commorientes, comentada mais acima, e inspirada no poeta grego Dífilo, mas que não chegou até nós (SPALDING. 1968: 63).

Sabe-se pouco da biografia plautina, mas sabe-se que, se retirou inspiração em expectativas de suspenses, cenas de reconhecimento entre pais e filhos ou entre amos e escravos, em moças ingênuas, na rivalidade entre o pai e o filho, em escravos trapaceiros (justamente porque o comediógrafo Plauto emblematizou certas situações por um traço típico nas reações dos comportamentos ladinos dos escravos, o escravo tem destaque especial no seu teatro), em parasitas aproveitadores, em velhos loucos e avarentos, em proxenetas e em prostitutas... porque, além de arriscar-se e se expatriar pela vida grega e cartaginesa das baixas classes sociais, aprendeu vulgarismos de linguagem, viveu em contacto com a Suburra (PARATORE, 1983: 51), um bairro de comunidade pobre na antiga Roma, o suficiente para desenvolver uma tipologia de personagens que povoam suas peças, explorando trocadilhos e toda a competência do sermo vulgaris, latim vulgar, em enunciações que chamou a atenção de autores canônicos, como por exemplo, Molière, William Shakespeare, Guilherme de Figueiredo, Ariano Suassuna etc.

A comédia grega pode ser dividida em Antiga e Nova. Na Antiga (século V), nomenclatura que indica características de vínculos com as origens, como nos elementos da composição e, assim um coro, que compõe um 'agón', um debate, sobre a 'pólis', (BRANDÃO, 1992: 72 - 73) com um protoganista (primeiro combatente). O elo da origem é o fato de o coro ser formado por animais (BRANDÃO, 1984: 74), tal como está nas alegorias dos títulos aristofânicos: As Rãs, As Vespas... o que lembrava os blocos de pessoas, portadoras ao ombro ou mascaradas de animais, nas falofórias, festas em honra do falo, e de cunho religioso, 'kómoi' religiosos, (Idem, ibidem: 74), ou seja, o princípio ' $\delta \eta ́ \mu ı \varsigma^{\prime}$, 'démios', próprio do povo, assinalado com o imaginário de um 'dêmos', povoação, povo; assembléia popular. Em Terêncio, Os Adelfos, há a personagem Dêmea, que significa "o que é popular", por antífrase, já que é uma personagem antipática, pois encarna o "pai severo" da tipologia da Comédia Nova.

A Comédia Antiga foi estruturada com uma parábase, momento em que uma personagem se despoja de suas características e se dirige antes aos cidadãos, quer dizer, toma a própria platéia, que assistia à peça, como se fossem os cidadãos gregos e, dada uma democracia bastante permissiva, as personagens não só eram pessoas tiradas do contexto histórico, como Sócrates, Eurípides, o governante Cleofonte, etc., como todas ridicularizadas como objeto de sátira veemente em Aristófanes.

Pierre Grimal, ao comentar sobre Terêncio, acentua que ele Nunca se dirige directamente aos espectadores, como faz Plauto por vezes - vestígio da antiga parábase... (1978: 113)

Na Comédia Nova, as características são outras, como já pontuamos alguma coisa. Nesta instância histórica, a Grécia experimenta o domínio de Alexandre Magno (século IV a.C.), quer dizer, é submetida a restrições políticas pelas tropas militares do macedônio Antípater; a comédia ática passa ao tema da "família" (BRANDÃO, 1984: 91) e a criar tipos estereotipados e não a mencionar mais alguém vivo ou morto, mas um 
tipo hipotético, por exemplo, um jovem de família, mas cheio de pretensões, se apaixona por uma moça, desprotegida e sob a guarda de um proxeneta que exige dinheiro pelo resgate da menina desamparada e o rapaz, impetuoso, termina por extorquir ao próprio pai. E assim se concebem farsas parodiadas em tramas burlescas com os tipos emblemáticos, mencionados em parágrafo anterior: escravos astutos, jovem libertino ou, às vezes, cordato, o soldado fanfarrão etc.

Plauto se distingue por tomar de uma, a Antiga - além da analogia à parábase em seus prólogos, com a mesma característica de captatio benevolentiae, captação da boa vontade - também se apropria da farsa; e da Comédia Nova se nota o seu envolvimento com o tema da estereotipada tipologia simbólica: A destilação dos motivos mais farsescos tirados da comédia nova obedece nele a uma propensão natural do seu espírito, alimentada pelo contacto com a plebe. (PARATORE, 1983: 48) O próprio nome do dramaturgo "Maccius" está em conexão com "Maccus" da "Atellana" (Idem, ibidem: 39) e denota o apelido de bobo, grotesco das máscaras atelanas... As fábulas atelanas eram comédias populares, simbolizadas nas máscaras maccus, o apalermado, buccus, o glutão e tagarela, pappus, o velho avaro etc. Além de predisposição ao riso satírico em diálogos, diverbia, a comédia de Plauto era um espetáculo com partes cantadas, cantica; enfim, uma comédia musical em senários iâmbicos...

À mímesis aristotélica que se traduz por vezes com o termo imitatio, mas, neste caso aqui, tem o sentido de representação do comportamento humano e encenado num drama teatral. Para Plauto, é uma verdade como imagem daquela sociedade, mas "verdade" no sentido de 'alétheia', ou seja, aquela contida no jogo de palavras, nas alegorias, metáforas e metonímias.

Em seu artigo da Principia VIII, "Ludi Scaenici" na Roma Antiga, Airto Ceolin comenta, na p. 106, que

o teatro latino em face do teatro grego: é um espetáculo lúdico. Insere-se no contexto dos jogos, "ludi". Os romanos o conheciam como "ludi scaenici", jogos de palco. Como espetáculo ("spec-“ olhar atentamente, observar, examinar) é para ser visto. Se é um espetáculo lúdico, deve ser examinado sob este aspecto. Precisa ser explicado segundo o contexto dos jogos, incluso como "otium", lazer, mas também como marca de uma civilização.

\title{
2
}

Quid pro quo

Em português, os quiproquós, umas coisas por outras, indicam que Plauto sabia muito bem ${ }^{6}$

\begin{abstract}
que le peuple n'apprécie guère ce que nous appelons les bienséances théatrales. L'art délicat qui consiste à préparer les situations et à lier les scènes n'est pas son fait: souvent les personnages entrent ou sortent sans motif apparent, et le dénouement est presque toujours brusqué. (HUMBERT, 1932: 48)
\end{abstract}

Daí, desses desenlaces bruscos, dénouement brusqué, ou como os chamaria Roland Barthes certas "lexias", fragmentos de linguagem, as quais, no teatro ('theatron', quer dizer, de onde se vê), ganham o relevo simbólico em sua expressão

\footnotetext{
${ }^{6}$ que o povo não aprecia o que nós chamamos de as conveniências teatrais. A arte delicada que consiste em preparar as situações e em ligar as cenas não é seu propósito (quer dizer, de Plauto): frequentemente os personagens entram ou saem sem motivo aparente, e o desenlace é quase sempre brusco.

7 "Lexia" é um termo introduzido por B. Pottier: é a manifestação singular de unidade léxica em um discurso.
} 
verbal ou "não-verbal" dentro da encenação. Assim, uma criatividade dramática cheia de surpresas, reviravoltas, peripécias, e reconhecimentos, anagnorises... Examinemos brevemente Menaechmi, Os gêmeos.

Plauto, num prólogo em forma de acróstico, se apresenta à plateia e dá o argumento da peça, o que é uma estratégia peculiarmente sua, de comunicação: uma captatio beneuolentiae. Era uma vez um pai de gêmeos (CHEVALIER e GHEERBRANDT, 1994: GÊMEOS e DUPLO - respectivamente $)^{8}$ parecidíssimos e, como um deles se perdeu do pai, durante uma viagem por Tarento, por descuido, caiu em mãos de um mercador, que se apossou da criança de sete anos. O pai se desesperou e veio a falecer de desgosto, aí mesmo, em Tarento. $\mathrm{O}$ avô que guardava o outro neto em Siracusa, por amor ao sequestrado, deu o mesmo nome, que é, inclusive, o seu também (et ipsus eodem est avos vocatus nomine, e o próprio avô se chama por este nome - v. 44), ao que ficou com ele em sua casa: illius nomen indit illi qui domi est, I Menaechmo, idem quod alteri nomen fuit; passou a chamar o nome dele àquele, que ficou em casa, Menecmo, porque tem do outro o mesmo nome. (v. 42-43)

Por trás do aparente alerta de um possível engano de interpretação do espectador no decorrer da ação dramática, Plauto, na verdade, dá ênfase ao seu leitmotiv, quer dizer, o fio condutor de sua enunciação e alerta que ora há de ficar em Epidano, onde atualmente vive o gêmeo sequestrado, para melhor narrar a história. Propõe fazer um favor a alguém da platéia, caso precise de algo de lá, pode pedir sem cerimônia: sed ita ut det unde curari id possit sibi, (v. 53) mas de tal modo que dê possibilidade de isto ser cuidado com o seu próprio recurso. Na feliz tradução de Jaime Bruna, que foi com consulta ao manuscrito, temos o seguinte: Se não me der dinheiro, o negócio vai por água abaixo; se der, vai mais abaixo ainda. Sua expressão corresponde ao v. 54: nam nisi qui argentum dederit, nugas egerit; (literalmente) pois, a não ser que alguém venha a dar algum dinheiro, nada terá conseguido. O raptor é um senhor rico, que não tinha filhos e adotou como tal o raptado. Sósicles, isto é, o Menecmo de Siracusa, viajou para Epidano para resgatar o seu irmão gêmeo.

Além do prólogo e indicação de personagens e o cenário, temos ao todo cinco atos com 23 cenas. E se tomarmos umas poucas "lexias" barthesianas do discurso plautino, depois das que ocorreram no prólogo, incluindo a última acima, cheia de simpática irreverência sobre o fato de fazer um favor aos que assistiam à peça, teremos possibilidade de contrapor as cenas, cheias de equívocos e mal-entendidos para provocar o riso, entre personagens tão idênticas, mas interiormente tão opostas não só no psiquismo, ou seja, na alma, mas também na identidade.

E tudo porque o liame de serem irmãos gêmeos fica oculto para as personagens, mas não para a plateia, o que é um jogo, ou melhor, truque, manipulado pelo Poeta. Os historiadores do teatro denominam "ilusão": a relação entre o espectador e o que ocorre nas cenas dramáticas. No caso das peças de Plauto, o espectador sabe tudo e as personagens não sabem de nada. Essa é uma troca de ponto de vista em que a "narrativa", tão bem manejada por Plauto, acontece na forma de narratários, ou melhor, dos que recebem a "mensagem narrativa" dentro da própria peça, como um artifício de

\footnotetext{
${ }^{8} \mathrm{O}$ simbolismo dos gêmeos nos introduz nos mundos contrários polares: masculino-feminino, trevas-luz, sujeito-objeto, interior-exterior...

A arte representa, em todas as culturas, animais em duplicata, serpentes, dragões, pássaros, leões, ursos etc. Não se trata de uma simples preocupação de ornamentação, nem é o indício de influência maniqueísta. Os animais representados têm, todos, uma dupla polaridade simbólica, benéfica e maléfica. ${ }^{9}$ Há ilusão teatral quando tomamos por real e verdadeiro o que não passa de uma ficção, a saber, a criação artística de um mundo de referência que se dá como um mundo possível, que seria o nosso. A ilusão está ligada ao "efeito do real" produzido pelo palco: ela se baseia no reconhecimento psicológico e ideológico de fenômenos já familiares ao espectador.
} 
"metatexto" (alguns preferem dizer "metateatro"). É a troca do "dono" do foco narrativo. É claro, no teatro não há propriamente um narrador. A relação é plateia e ação dramática - mas Plauto corta esse fio comunicativo e busca várias formas de contato, que denominamos mais acima de "captatio beneuolentiae".

Por exemplo, na Cena II (Menecmo e Escivunha), do Ato I, o personagem Menecmo censura a esposa e a ameaça. Tudo como estratégia para poder escapar. E nesta escapada, comenta num aparte, ou seja, só a plateia ouve o que ele fala, embora diga em voz alta e clara:

Euax, iurgio hercle tandem uxorem abegi ab ianua. ubi sunt amatores mariti? dona quid cessant mihi conferre omnes congratulantes, quia pugnavi fortiter? hanc modo uxori intus pallam surrupui, ad scortum fero sic hoc decet, dari facete verba custodi catae. (51-55)

Ótimo, com a briga, por Hércules, enfim afastei a minha mulher da porta. (à platéia)

Em que momento os maridos são libertinos? Por que todos retardam em oferecer presentes a mim em congratulação pelo que lutei corajosamente? Esta manta (mostra-a, sob o manto) há pouco, dentro de casa, furtei de minha mulher e vou levar para minha amante.

Assim se procede, com jeito, enredar com palavras à vigilante esperta.

Nesta Cena II, Escovinha faz um à parte, dizendo para a plateia que ele fingia estar zangado com esposa...

Plauto dialoga com a platéia diretamente, mas como ocorre em alguns prólogos seus, como no prólogo de Anfitrião que admite até a interferência do espectador. Depois de pedir à platéia boa vontade, quer dizer, silêncio e bastante atenção como justiça pelo ele, o deus Mercúrio, lhe oferece de vantagens, anuncia que se trata de uma tragédia. Nota, contudo, a contrariedade pelo fato de ser peça trágica. Veja:

quid? contraxistis frontem, quia tragoediam dixi futuram hanc? deus sum, commutavero. eandem hanc, si voltis, faciam ex tragoedia comoedia ut sit omnibus isdem vorsibus. utrum sit an non voltis? sed ego stultior, quasi nesciam vos velle, qui divos siem. teneo quid animi vostri super hac re siet: faciam ut commixta sit: <sit> tragicomoedia. nam me perpetuo facere ut sit comoedia, reges quo veniant et di, non par arbitror. quid igitur? quoniam hic servos quoque partes habet, faciam sit, proinde ut dixi, tragicomoedia. (58-63)

o que aconteceu? Franzistes o semblante, porque eu disse que a peça havia de ser uma tragédia? Sou deus, poderei mudá-la agora, se desejardes, trocarei de tragédia para comédia sem que se mude estes mesmos versos. Por acaso vós quereis, ou não? Mas que bobagem, Como se eu não soubesse o que vós quereis, eu que sou deus. Conheço o que existe no vosso íntimo sobre este assunto: Farei que seja (uma peça) mista: seja uma tragicomédia. Pois não julgo justo, onde existam reis e deuses, 
In Menaechmi, na passagem logo acima, este receptor é hipotético, pois não poderá responder jamais ao personagem Menecmo. Ele é fictício. Não é o ouvinte, ali na sua frente: o espectador presente na platéia. Para conseguir mais um exemplo mais claro, vejamos uma passagem ainda no Ato I, primeiramente na Cena I, PENICVLVS (que, metaforicamente, significa vassourinha ou escovinha):

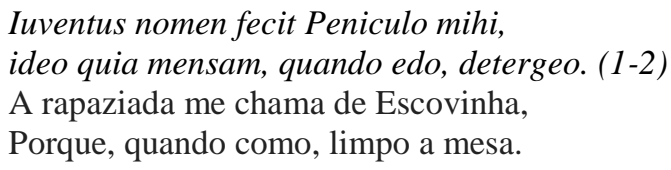

Só que, em Plauto, que só apareceu como narrador quando se dirigiu ao públicoespectador apenas no prólogo e, ainda assim, retirou o maior proveito possível da atenção do espectadores, pois que a presença no palco teatral já despoja a figura do narrador, ou seja, já vemos o desenrolar dos fatos.

Além dos apartes, o cômico latino dispõe em cenas a turbulência do equívoco que se origina da terrível semelhança do par gêmeo e seus respectivos escravos. A Cena II e III se destinam ao que Menecmo ("Verdadeiro") desejava: presentear Erócia com o manto. Esta há de preparar-lhe um jantar. Aí é que o Escovinha entra. É interessante a construção do equívoco, porque Menecmo II e seu servo Messenião encontram primeiramente Cilindro, de volta do mercado com os apetrechos da janta.

Por trás do riso há toda espécie de considerações sobre a condição feminina, a prepotência masculina, a situação dos escravos, o gosto humano de levar vantagem em tudo etc.

O Ato I, com três cenas, como já se disse, é um preparatório para os equívocos que ocorrerão no Ato II. Na ação dramática, o Poeta ainda injeta a ajuda da etimologia que já vem no nome da personagem em muitas de suas peças ou ele constrói na hora como nesta, da própria peça, e a ambiguidade que deveria confundir a plateia, ao contrário, dá lucidez e anima o riso. Assim, há o parasita Escovinha, Peniculus parasitus (por metáfora, escova) ${ }^{10}$, e como ele afirma: Peniculus Iuventus nomen fecit Peniculo mihi, ideo quia mensam, quando edo, detergeo, o nome Peniculus Juventus vem de pequena escova para mim, porque eu varro a mesa, quando como. (77-78) Menecmo de Epídano furta um manto da esposa e o dá à amante Erócia. Na Cena III o diálogo entre Erócia e Menecmo de Epidano, (tradução de Erotium Meretrix, Erócia Prostituta) cria elementos para equívocos das cenas futuras, porque ela não sabe com quem fala, mas pensa que sabe, como é no Ato II, cena III:

Men. Quicum haec mulier loquitur? Ee. Equidem tecum.

(Sosícles/ Menecmo II) (sem ser à parte falando para Messenião, servo deste): Com quem fala essa mulher?

(Erócia): Ora, com você.

Um erro é este da Cena II (Menecmo II e Messenião em diálogo com Cilindro [cozinheiro de Erócia]):

MEN. II Non hercle vero. CIL. Vbi convivae ceteri?

196

MEN. II Quos tu convivas quaeris? CIL. Parasitum tuom.

MEN. II Não, por Hércules, de fato (não sei quem é você). CIL. Onde estão os outros convidados?

\footnotetext{
${ }^{10}$ Peniculus, i, m.: (dim. de penis) extremidade de cauda de alguns animais que servia de escovinha; escova; vassoura.
} 
MEN. II Quais convidados procuras? CIL. Teu parasita. [...] CIL. Peniculum.

MESS. Peniculum eccum in vidulo salvom fero.

CIL. Escovinha.

MESS. A escovinha. Eis aqui trago salva na bolsa.

Ou seja, um fala de uma coisa, o outro de outra, como no diálogo entre Menecmo II e Meesenião com Erócia:

ER. Cur igitur me tibi iussisti coquere dudum prandium? 300

MEN.II Egone te iussi coquere?

$\boldsymbol{E} \boldsymbol{R}$. Por que mandaste que eu cozinhasse um jantar?

MEN.II Eu te mandei cozinhar?!

O manto furtado há de acabar (Ato II), por erro, na mão do outro, Sósicles (o gêmeo de Siracusa). Cena III (Erócia com Menecmo II e Messenião) (Ato II) - Nesta passagem abaixo o engano se acentua mais ainda:

MEN.II Nescio quem, mulier, alium hominem, non me quaeritas.

ER. Non ego te novi Menaechmum, Moscho prognatum patre, qui Syracusis perhibere natus esse in Sicilia, $\quad 320$ ubi rex Agathocles regnator fuit et iterum Phintia, tertium Liparo, qui in morte regnum Hieroni tradidit, nunc Hiero est? MEN.II Haud falsa, mulier, praedicas. MESS. Pro Iuppiter, num istaec mulier illinc venit, quae te novit tam cate?324 MEN.II (Decerto) não é a mim que procuras. Não sei, mulher, quem é o outro homem.

ER. Então, eu não te conheci como Menecmo, filho de Mosco, Que foi, segundo se cita, nascido em Siracusa, na Sicília, onde reinou Agátocles e em seguida Píntias e por terceiro Liparão, ao morrer, deixou o trono a Hierão, que agora reina?

MEN.II Mulher, falas tudo muito bem. MESS. Por Júpiter, acaso esta mulher, que te conhece tão bem, veio de lá?

(Ato IV) - Cena I (Matrona e Escovinha):

MAT. Egone hic me patiar frustra in matrimonio, ubi vir compilet clanculum quidquid domist atque ea ad amicam deferat? PEN. Quin tu taces? 465

MAT. Então eu sofrerei tamanha frustração no meu casamento, Enquanto meu marido às ocultas roubou coisas do lar E as desviou para sua amante? PEN. E ainda mais, tu calas? 465

[...] MAT.Quid ego nunc cum illoc agam? 472

PEN. Idem quod semper: male habeas; sic censeo.

[...] MAT.O que eu agora farei diante dele?

PEN. O que sempre fez: trate-o mal; assim penso. 
Cena III (Menecmo e Erócia)(ainda Ato IV):

MEN.I Immo edepol pallam illam, amabo te, quam tibi dudum dedi,

mihi eam redde. uxor rescivit rem omnem, ut factum est, ordine. ego tibi redimam bis tanto pluris pallam, quam voles.

ER. Tibi dedi equidem illam, ad phrygionem ut ferres, paulo prius,

et illud spinter, ut ad aurificem ferres, ut fieret novom.

MEN.I Ao contrário, por Pólux. Por favor, devolva para mim aquele manto, que te dei há pouco e te amarei (sempre). Minha esposa descobriu tudo que se passou em todos os detalhes. Eu te comparei outro com o dobro do valor, (do jeito) como quiseres.

ER. Ora, eu te entreguei, para que levasses para "oficina: de bordado e de ourives" com aquele bracelete, para que se fizessem renovados.

William Shakespeare se inspirou nesta peça e intitulou sua comédia de The Comedy of Errors, A Comédia dos Erros, onde também podemos fazer levantamento de situações humanas que fazem o espectador rir, mas reconhecer na aparente leveza do discurso o lado cruel da ação humana, embutida e permanente numa tradição preconceituosa e caduca. É o tema do duplo na arte, como reflexo de um espelho, cuja polaridade é benéfica e maléfica. É desse modo que as perturbações do eu vêm à tona através do riso, num humor que revela estádios primitivos, primários, trogloditas e marchetados na força da tradição.

O desdobramento final deixa a platéia bem humorada: a vida vale a pena ser vivida. Então, há libertação de escravos, reconciliações acontecem. Tudo "à maneira aristotélica", que se pode ler em Menandro (342 a 291 a.C.) como nesta interpretação do Prof. Junito (1984):

\footnotetext{
A idéia mestra de seu governo (Demétrio de Falero) é a criação de uma classe

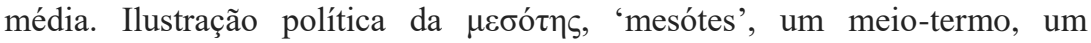
compromisso entre a aristocracia e a democracia. Tal aspiração explica na "Comédia Nova" como os casamentos, que fecham a ação, via de regra se realizam entre famílias ricas e pobres, como no "Misantropo" de Menandro, "Adelfos" de Terêncio e "Aululária" de Plauto
}

Não é este o conceito de 'katharsis' na poesia cômica de que nos fala Giovanni Lombardo? Sabe-se, conforme sua abordagem aqui e ali in "A Estética da Antiguidade Clássica", que a parte da comédia nos chegou incompleta, mas há muitos estudos que defendem, a partir de outras passagens que se leem em Aristóteles, a possibilidade de se compreender a 'katharsis' em equivalência com a experiência mimética. Esta última nos ajudando a satisfazer uma busca de conhecimento, sempre que o poeta ou o pintor, dada a sua habilidade em preparar relações entre pontos de afinidades diversas para os que usufruem o apelo trágico do acontecimento doloroso, perturbador da vida humana, mas se apresentará, eticamente, como injusto, e ipso facto alheio à vontade do homem, como ocorrera com Édipo, que viveu uma experiência dolorosa contra a qual lutou bravamente: a audiência experimentou diante do combate edipiano: éleos (compaixão) e phobus (medo) pari passu (a cada passo) durante os investimentos na sua luta. E na comédia? Os comentadores sustentam que Aristóteles não aponta qualquer 'kakia' 
(vício), mas apenas o feio 'aischron'(indecoroso, vergonhoso) que leva, conforme a habilidade artística, a ação dramática "para um adestramento ético e para para um prazer estético" (p. 97). Não é isso que se lê, comparativamente ao Plauto, em Victor Hugo, "Notre-Dame de Paris", onde o Quasímodo, sem culpa de sua fealdade, nutrepela bela cigana Esmeralda um amor puro, alheio à recepção de Esmeralda...

Podemos acrescentar quanto ao tipo de happy end tão antigo fica encadeado, com poucas modificações, na História do Ocidente para além de Shekespeare, para citar apenas alguns: Georges Feydeau (1862 - 1921), Guilherme de Figueiredo (1914 -1997) e Ariano Suassuna (1927), sem mencionar cinema, romances, telenovelas ... Tudo isso, significa que Plauto é poeta sem fronteiras. Mencionemos apenas mais um nome de nossa modernidade, em perspectiva comparada, que a apresentação da cenas de Menaechmi é a mesma técnica narrativa de Machado de Assis, onde o narrador se destitui do poder narrativo onisciente e "pede" ajuda ao leitor ou, então, atribui à personagem, ou ainda, o fato vem de uma versão de uma personagem qualquer. Por isso, o texto machadiano se torna facilmente uma peça de teatro ou um filme cinematográfico.

\section{Referências:}

AULO GÉLIO. Les Nuits Attiques. Traduction nouvelle avec Introducution et Notes par Maurice Mignon. Paris : Libraire Ganier Frères, s/d.

Aristote. Poétique. Texte établi et traduit par J. Hardy. Paris: Les Belles Lettres, 1932.

BAYET, Jean, Literatura Latina. Paris: Armand Colin, 1964.

BERTHOLD, Margot. História Mundial do Teatro. Tradução de Maria Paula V. Zuraswski et alii. São Paulo: Perspectiva, 2000.

BRANDÃO, Junito de Souza. Mitologia Grega. Petrópolis: Vozes, 1986. 3 v. Vols.I e II.

Dicionário Mítico-Etimológico da Mitologia Grega. Petrópolis: Vozes, 1992.

. Dicionário Mítico-etimológico da Mitologia e da Religião Romana.Petrópolis: Vozes, 1993.

Teatro Grego: Tragédia e Comédia. Petrópolis: Vozes, 1984.

Teatro Grego : Origem e Evolução. Petrópolis: Vozes, 1992.

BRAUSTEIN, F. e PÉPIN, Jean-François. L'Héritage de la Pensée Grecque et Latine. Paris : Armand Colin, 1997.

CARDOSO, Zélia de Almeida e DUARTE, Adriane da Silva (Orgs.) Estudos sobre o Teatro Antigo. São Paulo: Alameda, 2010. 
CASSIRER, Ernst. Antropologia Filosófica: Ensaio sobre o Homem. Introdução a uma Filosofia da Cultura Humana. Tr. de V. F. de Queiroz. São Paulo: Mestre Jou: 1977.

CHEVAliER, J. \& GHEERBRANDT, A. Dicionários de Símbolos. Trad. Vera Silva et alii. Rio de Janeiro: José Olympio, 1994.

CICÉRON. De l'Orateur. Texte établi, traduit et annoté par François Richard. Paris: Librairie Ganier Frères, s/d.

ERNOUT, A. et MEILLET, A. Dictionnaire Étymologique de la Langue Latine. : Histoire des Mots.Paris : Klincksieck, 1985.

GRIMAL, Pierre. O Teatro Antigo. Tradução de Antonio M. G. da Silva. Lisboa: Edições 70, 1978.

LOMBARDO, Giovanni. A Estética da Antiguidade Clássica. Trad, de Isabel Teresa Santos. Lisboa : Estampa, 2003.

MEILLET, A, Esquisse d'une histoire de la Langue Latine. Tradition de l'Humanisme II. Paris: Klincksieck, 1977.

MOISÉS, Massaud. Dicionário de Termos Literários. São Paulo: Cultrix, 1974.

MOMIGLIANO, Arnaldo. Os Limites da Helenização. Tradução de Cláudia Martinelli Gama. Rio de Janeiro: Jorge Zahar, 1975.

MONTAGNER, Airto Ceolin. "Ludi Scaenici” na Roma Antiga. Principia VIII, ano 6, 2002.

PARATORE, Ettore, História da Literatura Latina. Tradução de Manuel Losa, S. J., Fundação Calouste Gulbenkian, 13ª reimpressão, Lisboa, 1987.

PAVIS, Patrice. Dicionário de Teatro. Tradução sob a direção de J. Guinsburg e çMaria Lúcia Pereira. São Paulo: Perspectiva, 2011.

PEREIRA, Maria Helena da Rocha. Estudos de História da Cultura Clássica: Cultura Romana - Vol. II - Lisboa: Calouste Gulbenkian, 1982.

PLAUTE. Thêatre. Tome dexiéme. Traduction nouvelle de Henri Clouard. Paris: Librairie Ganier Frères, s/d.

SPALDING,T.O. Pequeno Dicionário de Literatura Latina. São Paulo: Cultrix, 1968.

Vieira, Brunno V.G. e THAMOS, Márcio (Orgs.). Permanência Clássica: Visões Contemporâneas da Antiguidade Greco-Romana. São Paulo: Escrituras, 2011. 